\title{
The effect of season and production systems on qualitative and quantitative properties of milk produced in dairy farms of Yazd province
}

\author{
Shokoohmand M, $\mathrm{MSc}^{1}$, Mofidi MR, $\mathrm{MSc}^{1}$, Bitaraf A, $\mathrm{MSc}^{1 *}$, Emami Meibodi MA, $\mathrm{PhD}^{2}$, Saeedabadi \\ $\mathrm{MS}, \mathrm{MSc}^{3}$ \\ 1- Faculty Member, Dept. of Animal Science, Agriculture and Natural Resources Research Center, Yazd, Iran. \\ 2- Assistant Prof., Dept. of Animal Science, Agriculture and Natural Resources Research Center, Yazd, Iran. 3- Faculty \\ Member Dept. of Veterinary Medicine, Agriculture and Natural Resources Research Center, Yazd, Iran.
}

\begin{abstract}
Received: May 2013, Accepted: November 2013

Background: Since milk is considered as one of the most common foods in human life, this research aimed to evaluate the quality of milk produced in traditional and industrial dairy farms of Yazd province in 2007.

Materials and Methods: In this descriptive study, six farms were selected in the cities Sadoogh, Yazd and Mehriz and sampling was performed in each of them bimonthly throughout one year. The samples were taken directly from udder, storage tanks (industrial farms) and containers (traditional farms) and were immediately sent to laboratory stored in ice. Total cell count was determined by bacterial culture test. Protein and fat percent, specific gravity $\left(\mathrm{g} / \mathrm{cm}^{3)}\right.$ and freezing point $\left({ }^{\circ} \mathrm{C}\right)$ were also measured.

Results: The results showed a significant increase in total cell count of samples at the time of shipment compared to those taken from udder $(\mathrm{P}<0.001)$. The total count in autumn and traditional farms was significantly higher than those in spring and industrial farms $(\mathrm{P}<0.01)$. Fat and protein percent, specific gravity and freezing point of milk showed the lowest and the highest significant values in summer and winter, respectively $(\mathrm{P}<0.01)$.

Conclusion: Based on the findings of this study, the low quality of milk in summertime could be improved by good management and implementing of proper feeding programs in dairy farms. It is possible to decrease microbial load to an acceptable level, particularly in traditional farms, by extension of new and efficient methods to farmers for disinfection and proper washing and drying of teat and mammary glands, tools and equipments used in milking along with immediate cooling of milk after milking.
\end{abstract}

Key words: Milk, hygiene, Industrialization, Traditional

\section{Introduction}

Milk as one of the most common foods in human's life is consumed directly without any further processing, so its physical (color and odor), chemical (fat and protein percent, freezing point, specific gravity etc.) and microbiological (microbial count and TCC) properties are of great importance [14]. They are affected by many factors such as genetic, milking stage, nutrition, age, mammary gland health, season, systems of production (traditional and industrial scales) etc. Depending upon the geographical region and climatic condition, the milk produced in different seasons has different quality.

To produce cream and cheese, protein and fat percent are the most important compounds that are considered by the milk

\footnotetext{
* Corresponding Author: Ahmad Bitaraf, Department of Animal Science, Agriculture and Natural Resources Research Center, Yazd, Iran. Email: a_btrf@yahoo.com
} 
processing plants. They are affected by many factors such as breed, daily milking frequency, milking stage, season, ambient temperature etc. Ozrenk and Selcuk Inci (2008) studied the effect of ambient temperature and seasonal effects on fat and protein percent in milk in Van province in Turkey. Sevi et al. (2004) showed that increase of day length induced some variation in milk production and its compounds in lactating ewes in southern Italy.

Freezing point is also an important qualifying specification because it is used to determine the probable addition of water to milk that increases melting point [11]. It is affected by many factors such as breed, milking stage, consumed water, climatic condition, season effects, heat stress etc $[10,12,13]$. The microbial load is a very important criterion to evaluate the quality status of milk that is an indication of freshness, mainly affected by ambient temperature and the primitive microbial load. According to International Dairy Federation (IDF) a microbial load higher than 20000 is an indication of a serious deficit in dairy farm hygiene whereas microbial loads lower than 20000 indicates milk production being in a good status [16]. High ambient temperature augments microbial grawth that multiplies the microbial population to many folds in a very short interval [4].

The milk quality of cows in Yazd province is highly different, affected by ambient temperature in different seasons in one hand and high magnitude of production in traditional farms (about 70 percent), on the other hand. Therefore, the objective of this study was to evaluate the qualitative status of milk production in traditional farms along with a simultaneous comparison with the industrial ones which in the long run would be helpful in determining the critically important factors affecting the food security of families.

\section{Material and Methods}

Since about 70 percent of Yazd provincial production comes from the cities of Yazd, Sadoogh and Mehriz, two randomly selected farms of each, a traditional and an industrial, were considered for sampling at present study. Milk sampling was performed within the year 2007, every two months directly from udder, milk storage tanks (industrial farms only) and in shipment. Udder sampling was performed six times a year, in five randomly selected cows in three industrial farms three times a day and three traditional ones two times a day, within 24 hours directly from teats (270 and 180 samples from industrial and traditional farms respectively). Sampling from storage tanks was performed only in industrial farms, six times a year from three farms, three samples in three times a day (162 samples). Sampling in shipment was performed six times a year, in three farms both in industrial and traditional farms, three samples a day from industrial farms (54 samples) and six ones from traditional ones (twice a day in the morning and the afternoon, 108 samples). Before sampling, the health of cow and its udder was tested and confirmed by an expert veterinarian. Then quarters were forestripped first to remove probable contaminated milk and then a sum of $200 \mathrm{ml}$ (50 $\mathrm{ml}$ from each quarter, the volume needed for microbial tests) was stripped into sterile pots, put immediately in the ice and sent to the laboratory.

The breed of cows in industrial farms was Holstein and in traditional ones was a hybrid of Holstein with local breeds. The animals in different farms were mostly fed with different proportions of hay (a mixture of wheat bran and Lucerne) and a concentrate 
(mostly a mixture of barley, wheat bran, cotton seed meal, mineral and vitamin supplements). The cows used in this study were of three to six years old. Sampling and testing of the milk was performed according to 5484 and 362 standards of ISIRI (Institute of Standard and Industrial Research of Iran) [10]. Fat and protein percent along with gravity and freezing point were measured by using Ekomilk machine (KAM 98-2A, BULTEH2000Ltd, Bulgaria). Microbial load was measured by counting the colonies formed in microbial culture. The logarithmic microbial load along with other data was analyzed by analysis of variance using SPSS software (ver. 11.5). Mean values were compared by Duncan's multiple range test.

\section{Results}

Table 1 shows the effects of rearing system and season on some factors of raw milk quality in Yazd province.

Table 1: The effects of rearing system and season on some factors of raw milk production quality in Yazd province

\begin{tabular}{|c|c|c|c|c|c|}
\hline \multicolumn{2}{|l|}{ Factors } & Fat \% & Protein \% & $\operatorname{Gravity}\left(\mathrm{g} / \mathrm{cm}^{3}\right)$ & Freezing Point $\left({ }^{\circ} \mathrm{C}\right)$ \\
\hline \multicolumn{2}{|l|}{ System } & $*$ & n.s & $* *$ & n.s \\
\hline \multicolumn{2}{|c|}{ Traditional } & $3.51 \pm 0.06^{\mathrm{a}}$ & $3.31 \pm 0.01$ & $1.0314 \pm 0.0001^{\mathrm{a}}$ & $-0.579 \pm 0.002$ \\
\hline \multicolumn{2}{|c|}{ Industrial } & $3.39 \pm 0.02^{\mathbf{b}}$ & $3.29 \pm 0.007$ & $1.0310 \pm 0.0001^{\mathrm{b}}$ & $-0.576 \pm 0.001$ \\
\hline \multicolumn{2}{|l|}{ Season } & $* *$ & $* *$ & $* *$ & $* *$ \\
\hline \multirow{2}{*}{ Spring } & Traditional & $3.51 \pm 0.15^{\mathbf{b}}$ & $3.33 \pm 0.02^{\mathbf{b}}$ & $1.0309 \pm 0.0002^{\mathrm{a}}$ & $-0.579 \pm 0.004^{\text {cb }}$ \\
\hline & Industrial & $3.28 \pm 0.04^{\mathbf{b}}$ & $3.29 \pm 0.01^{\mathrm{cd}}$ & $1.0306 \pm 0.0001^{\mathrm{ab}}$ & $-0.573 \pm 0.001 \mathbf{b c}$ \\
\hline \multirow{2}{*}{ Summer } & Traditional & $3.01 \pm 0.11^{\mathrm{c}}$ & $3.24 \pm 0.01^{\mathrm{e}}$ & $1.0303 \pm 0.0003^{\mathbf{b c}}$ & $-0.566 \pm 0.003^{a}$ \\
\hline & Industrial & $3.33 \pm 0.29^{\mathbf{b}}$ & $3.26 \pm 0.01 \mathrm{de}$ & $1.0300 \pm 0.0001^{\mathbf{b}}$ & $-0.569 \pm 0.001^{\mathbf{a b}}$ \\
\hline \multirow{2}{*}{ Autumn } & Traditional & $3.79 \pm 0.15^{\mathrm{a}}$ & $3.35 \pm 0.01^{\mathbf{a b}}$ & $1.0310 \pm 0.0002^{\mathrm{a}}$ & $-0.585 \pm 0.002^{\mathrm{d}}$ \\
\hline & Industrial & $3.47 \pm 0.05^{\mathbf{b}}$ & $3.30 \pm 0.01 \mathrm{bc}$ & $1.0294 \pm 0.0001^{\mathrm{d}}$ & $-0.580 \pm 0.001^{\mathbf{c d}}$ \\
\hline \multirow{2}{*}{ Winter } & Traditional & $3.85 \pm 0.09^{\mathrm{a}}$ & $3.37 \pm 0.01^{\mathrm{a}}$ & $1.0307 \pm 0.0001^{\mathbf{a b}}$ & $-0.584 \pm 0.002^{\mathrm{d}}$ \\
\hline & Industrial & $3.49 \pm 0.03^{\mathbf{b}}$ & $3.31 \pm 0.01$ bc & $1.0307 \pm 0.0001^{\mathrm{ab}}$ & $-0.577 \pm 0.001^{\mathbf{c}}$ \\
\hline
\end{tabular}

Values with different superscripts in column are significantly different at the levels of 0.05 and 0.01 designated with * and ** respectively. n.s.= no significant.

Table 2: Logarithmic least square mean $( \pm \mathrm{SE})$ of total microbial load in traditional and industrial systems in different seasons $(\log \mathrm{cfu} / \mathrm{ml})$

\begin{tabular}{lcccc}
\hline & \multicolumn{4}{c}{ Season } \\
\cline { 2 - 5 } Place of sample & Spring & Summer & Autumn & Winter \\
\cline { 3 - 5 } UM & $*$ & $* *$ & $* *$ & $* *$ \\
\cline { 1 - 3 } Traditional & $3.07 \pm 0.12^{\mathbf{d}}$ & $3.55 \pm 0.09^{\mathbf{d}}$ & $3.02 \pm 0.17^{\mathbf{c}}$ & $3.13 \pm 0.10^{\mathbf{c}}$ \\
\cline { 1 - 3 } Industrial & $3.80 \pm 0.06^{\mathbf{c}}$ & $4.08 \pm 0.09^{\mathbf{c}}$ & $3.33 \pm 0.09^{\mathbf{c}}$ & $3.65 \pm 0.06^{\mathbf{b}}$ \\
\hline TM & & & & \\
\cline { 1 - 3 } Industrial & $5.21 \pm 0.04^{\mathbf{b}}$ & $4.86 \pm 0.12^{\mathbf{b}}$ & $5.11 \pm 0.13^{\mathbf{b}}$ & $5.15 \pm 0.13^{\mathbf{a}}$ \\
\hline SM & & & & \\
\cline { 1 - 3 } Traditional & $5.58 \pm 0.09^{\mathbf{a}}$ & $5.87 \pm 0.07^{\mathbf{a}}$ & $6.14 \pm 0.08^{\mathbf{a}}$ & $5.61 \pm 0.12^{\mathbf{a}}$ \\
\hline Industrial & $5.23 \pm 0.16^{\mathbf{b}}$ & $5.24 \pm 0.21^{\mathbf{b}}$ & $5.43 \pm 0.14^{\mathbf{b}}$ & $5.31 \pm 0.20^{\mathbf{a}}$ \\
\hline
\end{tabular}

UM, TM and SM are the milk samples prepared immediately stripped from udder, milk storage tanks and milk in shipment respectively. Values with different superscripts in column are significantly different at the levels of 0.05 and 0.01 designated with * and ** respectively. Log cfu/ml= logarithmic value of colony-forming units per milliliter. 
Table 2 illustrates logarithmic least square mean $( \pm$ SE) of total microbial load in traditional and industrial systems in different seasons (logarithmic value of colony-forming units per milliliter, $\log \mathrm{cfu} / \mathrm{ml})$.

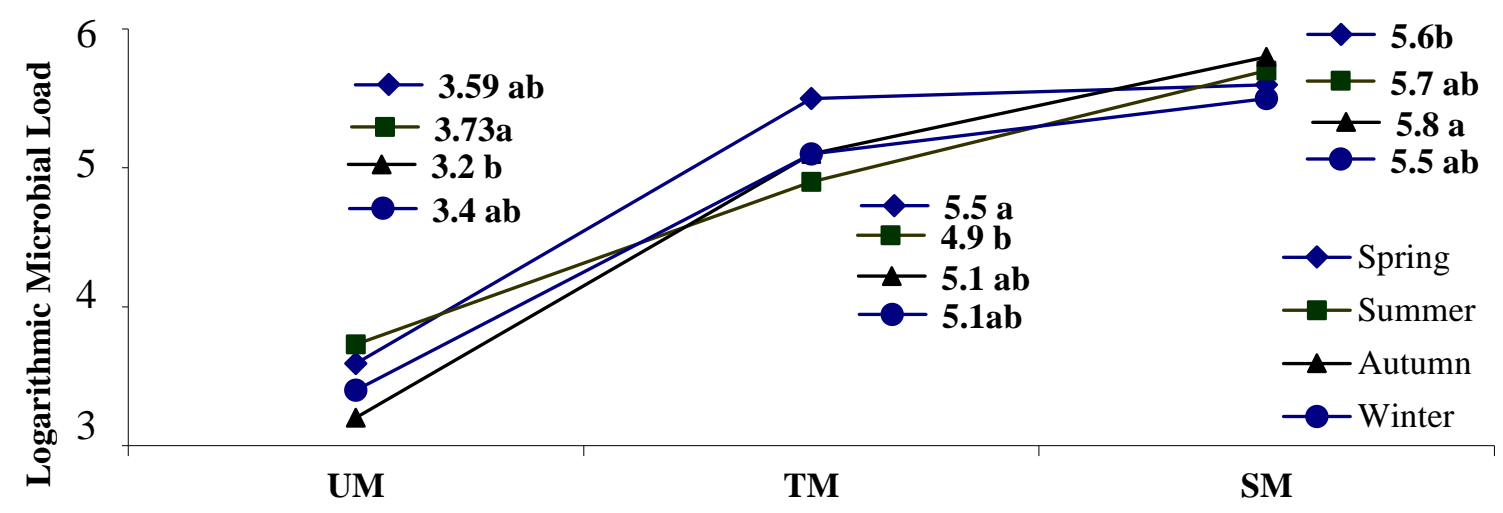

Figure 1: Seasonal total microbial load status of raw milk in Yazd Province dairy farms in different stages (UM, TM and SM are the milk samples prepared immediately stripped from udder, milk storage tanks and milk in shipment respectively)

In figure 1 , total microbial load status of raw milk in different stages, i.e. milk samples immediately stripped from udder, milk storage tanks and milk in shipment, are illustrated. Figure 2 shows total microbial load status of raw milk in traditional and industrial farms.

\section{Traditional Dairy Farms}

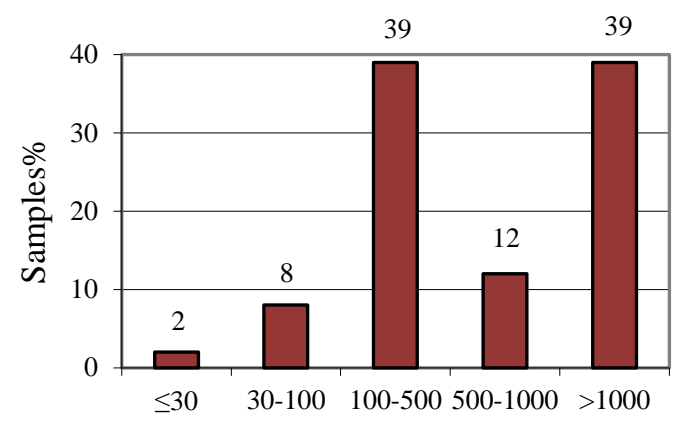

Total Count $(\times 1000)$
Industrial Dairy Farms

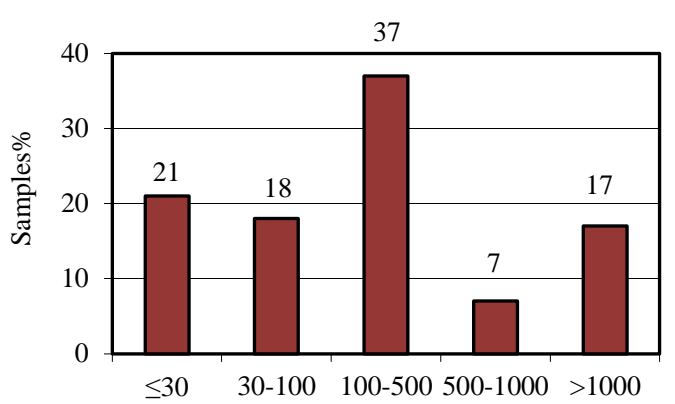

Total Count $(\times 1000)$

Figure 2: Total microbial load status of raw milk in traditional and industrial farms 


\section{Discussion}

According to the results of this study, the percentage of milk fat in traditional farms was higher than that of the industrial ones, being 3.5 and 3.39 percent respectively $(\mathrm{P}<0.05$, table 1) but protein percent, despite the higher value, was not significantly different. The least and the most significant percents of fat and protein in milk were observed in summertime and winter respectively $(\mathrm{p}<0.01$, table 1$)$. The higher levels of protein and fat percent of milk in traditional farms could be attributed to the two times daily milking rather than a three times schedule in industrials ones. Klei et al. (1997) in a study on Holstein cows in Cornell University showed that the total amount of milk, fat and protein in three times milking cows were 10.4, 5.0 and 7.0 percent more than the ones in two times milking cows but the fat and protein percent (three and six percent respectively) was higher in two times milking cows which coordinates with the results obtained at the present study. The recent studies show that there is a negative correlation between ambient temperature and the amount of milk fat and protein [16].

Increase in day length changes the amount and composition of milk that results in a decrease in total fat and protein. It is probably due to the higher concentration levels of prolactin in blood in summer that makes the milk diluted as reported by Sevi et al. (2004). Ozrenk and Selcuk Inci, (2008) reported a positive correlation between milk fat and protein percent that co-ordinately declines in hot weather but the milk protein is less fluctuated. They also studied the effect of seasonal variations on milk composition comprising the fat and protein percent in Van province in Turkey which showed the highest and the lowest proportions occurred in winter and summer respectively, despite the fact that the fat percent was more fluctuating (p<0.01). Kędzierska-Matyse et al. (2011) in a study in six breeds of cows in Poland showed that the fat percent of the milk produced in cold seasons (autumn and winter) despite a higher proportion, was not significantly different from that in hot seasons, summer and spring (4.28 viz. 4.15 percent). Contrary to fat percent, the protein percent in cold seasons was significantly higher than that in hot seasons (3.63 viz. $3.39 \%, \mathrm{p}<0.01)$ that was consistent with the results of the present study (3034 viz. 3.23\%, $\mathrm{p}<0.01)$. Some studies showed that the amount of short chain fatty acid in milk is significantly influenced by seasonal effects, scoring the highest and lowest values in summer and winter respectively [16].

The freezing points of milk produced in industrial and traditional systems determined at present study showed no significant differences, being -0.579 and $-0.576{ }^{\circ} \mathrm{C}$ respectively $(p>0.05)$ but the highest and the lowest values occurred in winter and summer respectively $(p<0.01$, table 1$)$. Freezing point is determined by proportion of components which by itself is affected by some factors such as breed, stage of lactation, consumed water, climatic conditions, seasonal effects, heat stress etc $[10,12,13]$. Freezing point is applied to recognize the milk quality that might be deliberately diluted with water. When it is less than $-0.535{ }^{\circ} \mathrm{C}$, the milk is free from any added water, between -0.534 and $-0.530{ }^{\circ} \mathrm{C}$ shows probable added water that needs further examinations and -0.529 to $-0.525^{\circ} \mathrm{C}$ decisively shows the raw milk was diluted with water [11]. The findings of present study showed no signs of added water in dairy farms of Yazd province. Kędzierska-Matyse et al. (2011) determined the effect of breed of cows on milk compositions and freezing point in Poland. The results showed that the average milk freezing point in different breeds of cows 
was between -0.54 and $-0.57{ }^{\circ} \mathrm{C}$ whereas in Jersey it was lower than that of Holstein cows $\left(-0.544\right.$ and $-0.537{ }^{\circ} \mathrm{C}$ respectively). There was no significant differences between the freezing point in production of autumn and winter with those of spring and summer (-0.538 viz. $\left.-0.537 \quad{ }^{\circ} \mathrm{C}\right) \quad[12]$; however, Brzozowski and Zdziarski (2005) reported a higher freezing point in autumn and winter in 196,891 samples of milk collected in 1,034 herds in Poland that coordinates with the results reported by Sawa and Oler (1999). Cais-Sokolińska and Wojciechowski (1995) in a study in Poland showed that the freezing point of milk in winters was lower than that in the summers which coordinates with the findings of the present study $(-0.583$ viz. $0.565, \mathrm{p}<0.01)$. Bjerg et al. (2005) reported that the highest and lowest freezing point in storage tanks occurred in summer and winter respectively that matches with this study. According to the findings of present study, higher limits of temperature, sunshine hours and increase of consumed water through the longer days would be among the reasons that increased the freezing point of milk in the summer time.

The specific gravity of milk produced in traditional farms was higher than that in industrial ones, being highest in winter and lowest in summer (Table1, $\mathrm{P}<0.01$ ). There is a simultaneous increase in water content and specific gravity of milk in summers due to the higher consumption of drinking water in hot weather. Azad et al. (2007) reported no significant differences for milk specific gravity in different months of the year in Bangladeshi cows $(p>0.05)$ that is inconsistent with the findings of present study. Ozrenk and Selcuk Inci (2008) reported no significant seasonal effects on specific gravity of milk whereas at present study the highest and the lowest gravities were observed in February $\left(1.0288 \mathrm{~g} / \mathrm{cm}^{3}\right)$ and October $\left(1.0262 \mathrm{~g} / \mathrm{cm}^{3}\right)$ respectively (average $1.026 \mathrm{~g} / \mathrm{cm}^{3}$ ).

There was also a significant difference for microbial loads of the milk immediately stripped from udder in all seasons except autumn in both systems of traditional and industrial dairy farms at present study (table $2, \mathrm{p}<0.01)$. The lowest total microbial load of storage tanks in industrial dairy farms in summer could be related to the using of cooling systems in summertime. There was the highest change in total microbial load from the time of storage to the time of milk shipment in summer. The lowest and highest microbial load during shipment in both systems occurred in autumn and spring respectively. Significant differences were observed between traditional and industrial farms for microbial load averages in shipment ( $p<0.01$ and $p<0.05$ respectively) in all seasons except winter in the present study (table 2). In a research in Ireland, Berry et al. (2006) reported higher total bacterial counts during fall and winter and lower ones during spring. Elmoslemany et al. (2009) reported that total aerobic count tended to be high during summer and low during winter that is inconsistent with the findings of present study. Microbial load of stripped milk in spring, summer, autumn and winter were $10^{3.59}, 10^{3.73}, 10^{3.2}$ and $10^{3.4}$ respectively that increased to $10^{5.6}, 10^{5.7}, 10^{5.8}$ and $10^{5.5}$ for the milk in shipment but the most increasing trend observed from stripped milk to milk stored in storage tanks (figure 1, table 2). Significant differences in microbial load averages for stripped and stored milk were observed among different industrial dairy farms ( $p<0.01, p<0.05$ respectively) but the difference between stored stage and shipment was not significant ( $p>0.05$, table 2) which is the result of using storage tank with cooling system in industrial farms that stops or reduces the microbial grawth to the lowest 
rate. Prejit-Nanu et al. (2007) showed that raw milk storage in dairy farms at 7 to $10^{\circ} \mathrm{C}$ for 17 hours did not make any significant difference in total microbial load. The logarithmic microbial load in stripped and stored stages was 5.14 and $5.7 \mathrm{cfu} / \mathrm{ml}$ (colony-forming units per milliliter) respectively being higher than that determined at present study (table 2). Bonfoh et al. (2003) in a study in Mali showed milk microbial load of stripped milk was $10^{3}$ that increased to $10^{7}$ at the time of consumption. The results of present study showed about 50 and 75 percent of raw milk produced in traditional and industrial farms had less than 500000 microbes per $\mathrm{ml}$ (figure 2). In the aforementioned farms, about 17 and 39 percent of the produced raw milk had more than one million microbes per ml. ISIRI (2008) has ranked the raw milk as excellent, grade 1, grade 2 and grade 3 based on the maximal acceptable microbial load that set at $<3 \times 10^{4}, 3 \times 10^{4}$ to $10^{5}, 10^{5}$ to $5 \times 10^{5}$ and $5 \times 10^{5}$ to $10^{6}$ per ml respectively.

According to the figure 2, twenty one percent of milk produced in industrial dairy farms is excellent, whereas in the traditional farms, it comprises only two percent. This finding necessitates more attention towards the milking hygiene, particularly in traditional dairy farms. It is noteworthy that about 40 percent of milk produced in Yazd province is categorized at third level (with microbial load about $5 \times 10^{5}$ to $10^{6}$ per $\mathrm{ml}$ ). Boor et al. (1998) showed that 58 and 30 percent of milk samples taken in Newark had less than 100000 and 25000 (standard level) respectively, whereas about $42 \%$ of samples were from production under inappropriate hygienic conditions. In a study accomplished in South Africa at small scale farms, only 25 of raw milk samples taken from dairy farms had a microbial load at or less than the standard level [14].
Elmoslemany et al (2009) reported that approximately 50 and 71 percent of the milk samples in Prince Edward Island had $<5,000$ and $<10,000$ microbial loads respectively. One of the main factors effective in establishing the final raw milk microbial load is the early load pre-existed in milk. As illustrated in table 2, the highest milk microbial load in udder stage causes the higher load in shipment. Not immediately but a few hours after milk was stripped from udder, the microbial progressive grawth will start. This delayed time is a good opportunity to make milk cool and keep it at a desired temperature (under $4{ }^{\circ} \mathrm{C}$ ) in order to control the bacterial grawth. By shortening the time spent for decreasing the temperature of stripped milk to $4{ }^{\circ} \mathrm{C}$, the final milk microbial load will also decrease.

As shown in table 2, milk microbial load in udder from traditional farms is lower than that from industrial farms that is contrary to the milk loads in shipment from these farms. The lower loads of immediate stripped milk in traditional dairies is a sign of less damage to udder and teat which is due to less production in traditional farms on one hand and for the more care paid to udder hygiene and washing due to the smaller number of cows in these farms on the other hand. However, lack of milk chillers, proper disinfecting milking tools and warm water in traditional farms resulted in rapid increasing of milk microbial load within and after milking. Zweifel et al. (2005) in a study in 403 different farms throughout Switzerland concluded that the main effective factors in producing milk of high quality were accomplished by improvement of hygienic conditions, control and service of milking machines and tools, rapid cooling of raw milk and collecting milk from small dairy farms as soon as possible. 


\section{Conclusions}

According to the results obtained at present study, the milk produced in Yazd province was not qualified as suitable product particularly in traditional farms since a high proportion of production had more than 500000 microbes per ml when this study was carried out in 2007. Although the milk at udder stripping stage had less than 5000 microbes per $\mathrm{ml}$, exponentially grawth of microbes caused by using polluted milking tools led to the production of milk below the standard criterion at the shipment stage. Hence the following suggestions are presented to improve the milk quality in Yazd province:

- Extension of new and efficient methods to farmers and workers for disinfection and proper washing and drying of teat and mammary glands, disinfection of containers, tools and equipments used in milking and urgency in rapid cooling of milk.

- Urgent delivery of milk in the traditional farms to the milk collecting stations.

- Implementing a grading and payment system to qualify the milk at the entrance of processing plants based on microbial load, chemical and physical properties.

\section{Acknowledgements}

Authors would like to thank the authorities of Jihad-e-Agriculture Organization of Yazd Province for their assistance in providing a part of budget for conducting this research.

Conflict of Interest: Non declared

\section{References}

1. Azad MA, Hasanuzzaman M, Azziunnesa Shil, GC, Barik MA. Milk production trend, milk quality and seasonal effect on it at Baghabarighat milk shed area, Bangladesh. Pakistan Journal of Nutrition 2007; 6(4):3635.

2. Berry DP, O'Brien B, O'Callaghan EJ, Sullivan KO, Meaney WJ. Temporal trends in bulk tank somatic cell count and total bacterial count in Irish dairy herds during the past decade. J Dairy Sci 2006; 89(10):408393.

3. Bjerg M, Rasmussen MD, Nielsen MO. Changes in freezing point of blood and milk during dehydration and rehydration in lactating cows. J Dairy Sci 2005; 88(9):317485.

4. Bonfoh B, Wasem A, Traoré AN, Fané A, Spillmann H, Simbé CF, et.al. Microbiological quality of cow's milk taken at different intervals from the udder to the selling point in Bamako (Mali). Food Control 2003; 14(7):495-500.

5. Boor KJ, Brawn DP, Murphy SC, Kozlowski SM, Bandler DK. Microbiological and Chemical Quality of Raw Milk in New York State. J Dairy Sci 1998; 81(6):1743-8.

6. Brzozowski P, Zdziarski K. Freezing point of udder-milk in milk producing cows. Med Weter 2005; 61(8):934-6.

7. Cais-Sokolińska D, Wojciechowski J. Analysis of the dilution level in raw milk. Polskie Zwierzę ta Gospodarskie 1995; 3:5-6.

8. Elmoslemany AM, Keefe GP, Dohoo IR, Dingwell RT. Microbiological quality of bulk tank raw milk in Prince Edward Island dairy herds. J Dairy Sci 2009; 92(9):4239-48.

9. Henno M, Ots M, Jõudu I, Kaart T, Kärt O. Factors affecting the freezing point stability of milk from individual cows. Int Dairy $\mathbf{J}$ 2008; 18(2):210-15.

10. Institute of Standard and Industrial Research of Iran (ISIRI). Microbiology of milk and milk products. Institute of Standard and Industrial Research of Iran: Tehran. Standard numbers: 326. ( $2^{\text {nd }}$ Revision); 2008. PP5484, 2406.

11. Janštová $B$, Navrátilová $P$, Dračková $M$, Přidalová $\mathrm{H}$, Vorlová L. Impact of heat treatment on the freezing points of cow and goat milk. Acta Vet Brno 2009; 78(4):67984. 
12. Kędzierska-Matysek M, Litwińczuk Z, Florek M, Barłowska J. The effects of breed and other factors on the composition and freezing point of cow's milk in Poland. Int J Dairy Technol 2011; 64(3):336-42.

13. Klei LR, Lynch JM, Barbano DM, Oltenacu PA, Lednor AJ, Bandler DK. Influence of Milking Three Times a Day on Milk Quality. J Dairy Sci 1997; 80(3):427-36.

14. Lues JFR, De Beer H, Jacoby A, Jansen KE, Shale K. Microbial quality of milk, produced by small scale farmers in a peri-urban area in South Africa. Afr J Microbiol Res 2010; 4(17): 1823-30.

15. Ozrenk E, Inci SS. The Effect of seasonal variation on the composition of cow milk in van province. Pakistan Journal of Nutrition 2008; 7(1):161-4.
16. Prejit EN, Latha C. Microbial quality assurance of milk during production, processing and marketing. American Journal of Food Technology 2007; 2(3):136-44.

17. Sawa A, Oler A. Influence of mastitis and the selected environmental factors on the yield, composition and quality of milk. Zesz. Nauk. Prz. Hod. PTZ 1999; 44:225-33.

18. Sevi A, Albenzio M, Marino R, Santillo A, Muscio A. Effects of lambing season and stage of lactation on ewe milk quality. Small Rumin Res 2004; 51(3):251-9.

19. Zweifel C, Muehlherr JE, Ring M, Stephan R. Influence of different factors in milk production on standard plate count of raw small ruminant's bulk-tank milk in Switzerland. Small Rumin Res 2005; 58(1):63-70. 